\title{
Perancangan Aplikasi Digital Untuk Mencatat Data Tamu Menggunakan Near Field Communication (NFC) (Studi Kasus Humas \& Rekrutmen Politeknik Pos Indonesia)
}

\author{
Roni Andarsyah ${ }^{1}$, M. Harry K Saputra ${ }^{2}$ \\ Program Studi D4 Teknik Informatika, Politeknik Pos Indonesia ${ }^{1}$ \\ email: roniandarsyah@poltekpos.ac.id ${ }^{1}$ \\ Program Studi D4 Teknik Informatika, Politeknik Pos Indonesia ${ }^{2}$ \\ email: harrysaputra@poltekpos.ac.id ${ }^{2}$
}

\begin{abstract}
Abstrak
Buku tamu pada unit Humas dan Rekrutmen Politeknik Pos Indonesia digunakan untuk mencatat pengunjung/tamu/pihak luar yang datang, baik perorangan maupun korporasi. Buku tamu dicatat dalam sebuah buku dimana hal tersebut rentan sekali untuk hilang, apalagi buku tamu sering dipinjam unit lain dan lupa untuk dikembalikan. Selain itu kehilangan buku tamu sering terjadi ketika adanya penggantian kepengurusan pada unit Humas dan Rekrutment. Permasalahan lain terjadi ketika tamu atau pengunjung yang hadir terkadang lupa untuk mengisi buku tamu sehingga menyulitkan dalam proses mencari data tamu yang hadir untuk keperluan kerjasama pada suatu unit, Ketika tamu datang berulang kali maka buku tamu harus diisi berulang, hal tersebut menyebabkan duplikasi data. Dari hasil analisis dan perancangan buku tamu secara digital dengan memanfaatkan E-KTP dimana didalamnya sudah terdapat Near Field Communication (NFC) sudah dapat diimplementasikan dan dimanfaatkan untuk proses identifikasi seseorang. Pembacaan NFC pada E-KTP memanfaatkan mikro komputer Arduino Uno dan sensor NFC PN532 dan terhubung pada jaringan, sehingga data bisa disimpan pada server dan dapat diakses oleh semua unit yang ada di Politeknik Pos Indonesia. Dengan memanfaatkan E-KTP data yang diinputkan pengguna dapat dipastikan sesuai dengan data diri tamu yang datang tanpa adanya pemalsuan identitas dan apabila tamu datang berulang kali maka tamu cukup melakukan tapping E-KTP pada alat yang disediakan. Dengan demikian data tamu dapat dipastikan sesuai dengan identitas diri yang sah yaitu E-KTP dan dalam hal ini seluruh data tamu dapat diakses oleh semua unit yang ada di lingkungan Politeknik Pos Indonesia untuk keperluan komunikasi atau kerja sama dengan pihak luar.
\end{abstract}

Kata Kunci: Buku Tamu, E-KTP, Near Field Communication (NFC), Sensor NFC PN532.

Abstract

The guest book at the Pos Indonesia Polytechnic Recruitment and Public Relations Unit is used to record visitors/guests / outside parties, both individuals and companies. Guest books are recorded in books that are very vulnerable to lose, especially because they are often borrowed by other units and forgotten to be returned. In addition, the loss of guest books often occurs when there is a change in management in the Public Relations and Recruitment section. Another problem occurs when guests or visitors who attend sometimes forget to fill in the guest book so it is difficult in the process of finding guest data that is present for the purpose of working together in one unit. When guests come repeatedly, the guest book must be filled repeatedly, this causes data duplication. From the results of the analysis and digital design of the guest book by utilizing the existing E-KTP Near Field Communication (NFC) can already be implemented and utilized for the process of identifying someone. NFC reading on the E-KTP uses an Arduino Uno microcomputer and PN532 NFC sensor and is connected to the network, so data can be stored on the server and can be accessed by all units at Polytechnic Pos Indonesia. By utilizing E-KTP, the data entered by the user can be ascertained in accordance with the data of guests who arrive without falsification of identity and if guests come repeatedly, guests simply tap E-KTP on the tools provided. Thus guest data can be ascertained in accordance with a valid personal identity that is E-KTP and in this case, all guest data can be accessed by all units in Polytechnic Pos Indonesia for communication or cooperation with external parties.

Keywords: Guest Book, E-KTP, Near Field Communication (NFC), PN532 NFC Sensor. 


\section{PENDAHULUAN}

Humas dan Rekrutmen Politeknik Pos Indonesia sebuah unit yang ada di lingkungan institusi Politeknik Pos Indonesia dalam rangka menetapkan strategi penerimaan mahasiswa baru serta merencanakan, mengendalikan dan mengembangkan sistem kehumasan diantaranya menjalin kerjasama, dokumentasi data tamu dan follow up tamu guna menjamin citra institusi yang lebih baik di kalangan stakeholder.

Buku tamu adalah catatan atau data yang berisi tentang identitas pengunjung di suatu tempat atau perusahaan yang berisi nama, alamat, dan tujuan [1], Pada unit Humas dan rekrutmen pengisian data tamu masih dilakukan secara manual yaitu dengan cara tamu mengisi beberapa kolom data diri yang disediakan pada sebuah buku.

Penyimpanan data tamu secara manual pada sebuah buku rentan terjadinya kehilangan data, hal tersebut terjadi karena data buku tamu seringkali dipinjam oleh unit lain yang memerlukan informasi kontak dari perusahaan pada data tamu yang pernah hadir, dan lupa untuk dikembalikan, selain itu jika terjadi pergantian kepengurusan Humas dan Rekrutmen, data buku tamu tidak diperhatikan sebagai data yang penting sehingga tidak jarang buku tamu hilang.

Selain sering terjadinya kehilangan buku tamu, data yang ada didalamnya tidak bisa dipastikan kebenarannya dengan identitas yang sah, sehingga menyulitkan melakukan identifikasi jika terjadi hal hal yang tidak diinginkan.

Buku tamu digunakan oleh unit Humas dan rekrutmen untuk kebutuhan PR (Public Relation), terkadang dibutuhkan oleh unit lain yang ada dilingkungan Politeknik Pos Indonesia untuk menghungungi pihak luar, biasanya digunakan untuk keperluan kerjasama, MOU atau mencari pembicara untuk kegiatan tertentu.

Jika data pada buku tamu tidak sesuai atau hilang maka akan menyulitkan semua unit untuk menghubungi pihak luar tadi, Oleh sebab itu unit Humas dan Rekrutmen melakukan digitalisasi pada buku tamu dan memanfaatkan teknologi IOT (Internet of Thinks) yaitu mikro komputer Arduino Uno untuk melakukan komputasi dan sensor NFC PN532 untuk membaca Near Field Communication (NFC) kartu pada E-KTP, serta data disimpan pada server kampus maka semua unit yang memiliki hak akses dapat menggunakan data tamu tersebut untuk kebutuhan masing masing.

Data yang dibaca pada E-KTP hanya id dari kartunya yang kemudian diinputkan data diri misalnya nama, nama instansi/perusahaan, nomor telpon yang bisa dihubungi, alamat email sebagai data awal, selanjutnya jika tamu tersebut datang kembali cukup melakukan taping E-KTP dimana sistem akan mencari data berdasarkan id pada Near Field Communication (NFC) E-KTP dan pengunjung/tamu cukup mengisi tujuan kedatangan saja pada field yang disediakan. Dengan demikian waktu pengisisian data lebih ringkas dan data identitas diri tidak berulang.

\section{LANDASAN TEORI}

\subsection{Near Field Communication (NFC)}

Near Field Communication atau yang biasa disebut NFC adalah teknologi komunikasi nirkabel yang berjarak pendek dan berfrekuensi tinggi yang muncul dari konvergensi identification contactless seperti RFID dan jaringan teknologi seperti bluetooth dan Wi-Fi, NFC dapat diinsialisasi dengan cara menyentuh atau menekan satu perangkat NFC ke perangkat lain.

Teknologi NFC memungkinkan interaksi sederhana dua arah dan aman antara perangkat elektronik, yang memungkinkan konsumen untuk melakukan transaksi tanpa kontak, mengakses konten digital, dan menghubungkan perangkat elektronika dengan satu sentuhan. Dengan memanfaatkan elemen kunci dalam standar yang ada untuk teknologi kartu tanpa kontak (ISO/IEC 14443 A \& B dan JIS-X 6319-4). 
NFC dapat kompatibel dengan infrastruktur kartu tanpa kontak yang ada dan memungkinkan konsumen untuk memanfatkan salah satu perangkat di sistem yang berbeda (Farid, 2015).

\subsection{E-KTP}

Berdasarkan Permendagri Nomor 9 Tahun 2011 tentang penerbitan Kartu Tanda Penduduk Berbasis Nomor Induk Kependudukan Secara Nasional dalam Pasal 1 ayat (9) menjelaskan tentang KTP berbasik NIK secara Nasional yang selanjutnya disingkat E-KTP adalah KTP yang memiliki spesifikasi dan format KTP Nasional dengan sistem pengamanan khusus yang berlaku sebagai identitas resmi yang diterbitkan oleh Dinas Kependudukan dan Pencatatan Sipul Kabupaten/Kota.

E-KTP atau Kartu Tanda Penduduk adalah merupakan dokumen kependudukan yang memuat sebuah sistem keamanan/pengendalian baik dari sisi administrasi ataupun teknologi informasi dengan berbasi pada database kependudukan nasional. Penduduk hanya diperbolehkan memiliki 1 (satu) KTP yang tercantum Nomor Induk Kependudukan (NIK). NIK merupakan identitas tunggal setiap penduduk dan berlaku seumur hidup. Nomor NIK yang ada di EKTP nantinya akan dijadikan dasar penerbitan paspor, Surat Izin Mengemudi (SIM), Nomor Pokok Wajib Pajak (NPWP), Polis Asuransi, sertifikat atas hak tanah dan penerbitan dokumen identitas lainnya.

Tujuan penerbitan KTP Elektronik (e-KTP) berdasarkan Permendagri Nomor 9 tahun 2011 pasal 2, pemerintah menerbitkan KTP Elektronik untuk mewujudkan kepemilikan satu KTP untuk satu penduduk yang memiliki kode keamanan dan rekaman elektronik data kependudukan berbasis NIK secara Nasional (B.D. Fajar, 2014).

\subsection{Arduino Uno}

Arduino Uno adalah sebuah rangkaian yang dikembangkan dari mikrokontroller berbasis ATmega328. Arduino Uno memiliki 14 kaki digital input/output, dimana 6 kaki digital diantaranya dapat digunakan sebagai sinyal PWM (Pulse Width Modulation). Sinyal PWM berfungsi untuk mengatur kecepatan perputaran motor. Arduino Uno memiliki 6 kaki analog input, kristal osilator dengan kecepatan jam 16 $\mathrm{MHz}$, sebuah koneksi USB, sebuah konektor listrik, sebuah kaki header dari ICSP, dan sebuah tombol reset yang berfungsi untuk mengulang program (Soraya, 2014).

\subsection{Metode Prototype}

Prototype merupakan salah satu metode pengembangan perangat lunak yang banyak digunakan. Dengan metode prototyping ini pengembang dan pelanggan dapat saling berinteraksi selama proses pembuatan sistem. Prototyping, dimulai dengan pengumpulan kebutuhan pelanggan terhadap perangkat lunak yang akan dibuat, mendefinisikan objektif keseluruhan dari software, mengidentifikasikan segala kebutuhan, kemudian dilakukan "perangcangan kilat" yang difokuskan pada penyajian aspek yang diperlukan agar pelanggan lebih terbayang dengan apa yang sebenarnya diinginkan. Berikut adalah gambar dari model prototype: (A. Pratama, 2013)

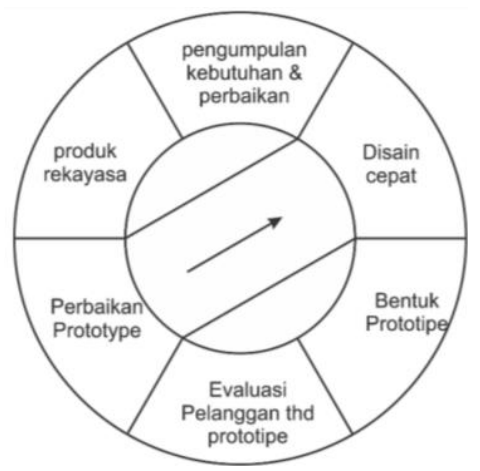

Gambar 1. Ilustrasi Model Prototype 


\subsection{METODE PENELITIAN}

Metodologi penelitian yang digunakan pada penelitan ini terdiri dari Analisa kebutuhan dan identifikasi masalah, studi litilatur dan perancangan system, perancangan aplikasi atau sistem informasi, implementasi dan kesimpulan

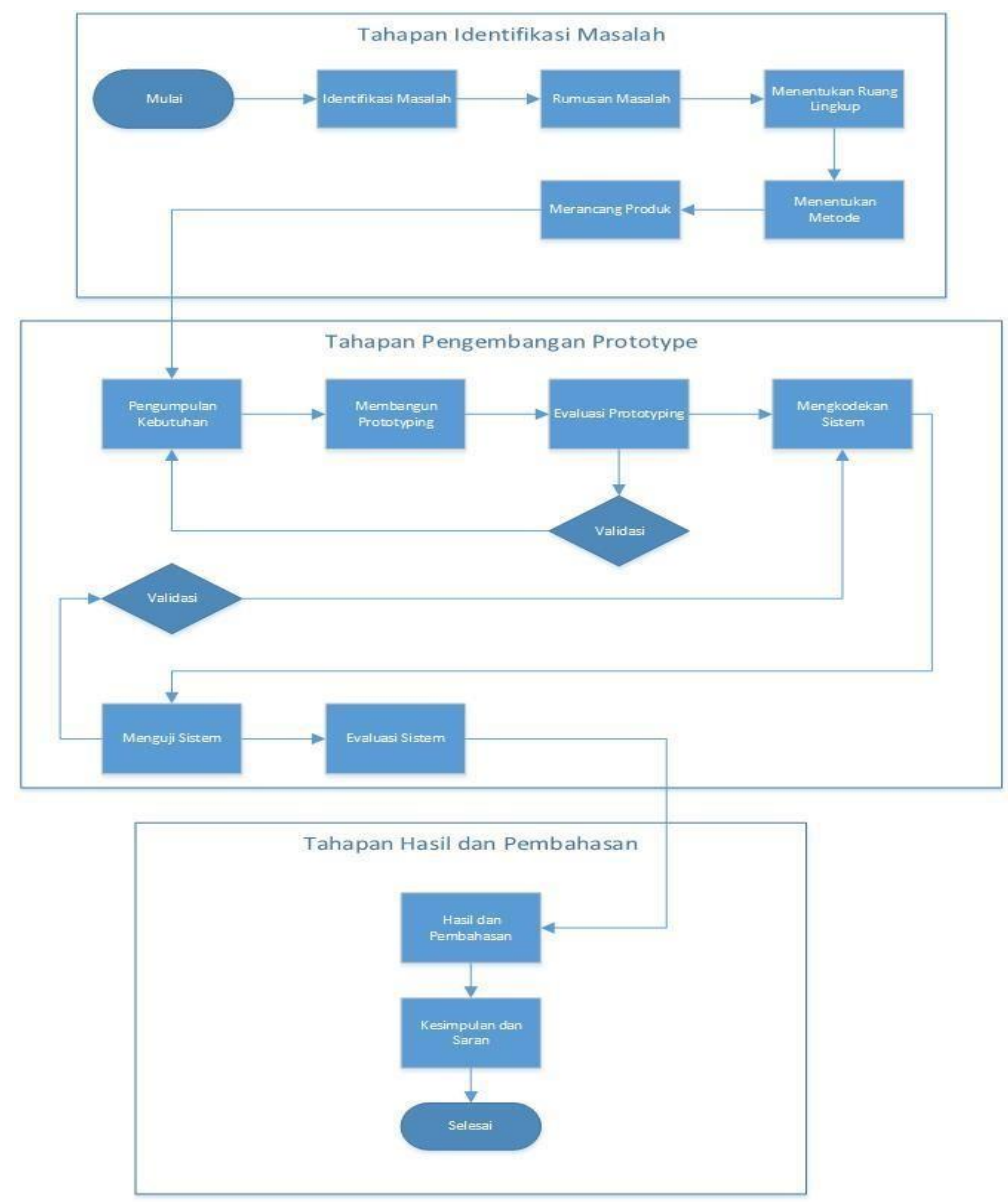

Gambar 2. Tahapan dan Alur Penelitian

Tahapan dari metode penelitian yang akan dilakukan yaitu berdasarkan pada diagram alur metodologi penelitian di atas adalah sebagai berikut:

\subsubsection{Tahapan Identifikasi Masalah}

Pada tahap ini terdiri dari beberapa proses diantaranya ;

1. Mengidentifikasi adalah melakukan identifikasi masalah dari proses dokumentasi buku tamu sampai dengan proses distribsi data tamu kepada unit lain yang membutuhkan.

2. Melakukan pemecahan masalah tersebut berdasarkan dengan studi literature dari beberapa sumber yang berkaitan dengan penelitian yang akan dilakukan ini.

3. Melakukan studi pustakayang disesuaikan dengan keterkaitan dan potensi yang sesuai dengan penelitian yang dilakukan

4. Menentukan tujuan penelitian ddibuat dengan mengacu kepada beberapa permasalahan yang sudah teridentifikasi sebelumya yaitu merancang aplikasi digital untuk mencatat data tamu menggunakan arduino uno dan near-field communication (NFC) 


\subsubsection{Tahapan Pengembangan Prototype}

Pada tahap pengembangan prototype yang akan dilakukan pada penelitian ini terdiri dari

1. Pengumpulan kebtuhan terkait apa saja yang dibutuhkan untuk mendapatkan solusi pencatatan data buku tamu tersebut

2. Membangun prototype dengan cara membuat blueprint dan desain user interface yang akan dibuat terdiri dari user interface system dan hardware

\subsubsection{Tahapan Hasil}

Pada tahap hasil dan pembahasan pengembangan prototype yang akan dilakukan pada penelitian ini terdiri dari

1. Melakukan evaluasi prototype system pencatatan data tamu yang dibuat

2. Melakukan pengujian langsung pada aplikasi Arduino untuk mencatat data tamu menggunakan NFC

3. Evaluasi hasil dari pencatatan tamu

3. HASIL DAN PEMBAHASAN

3.1 Analisis sistem yang sedang berjalan

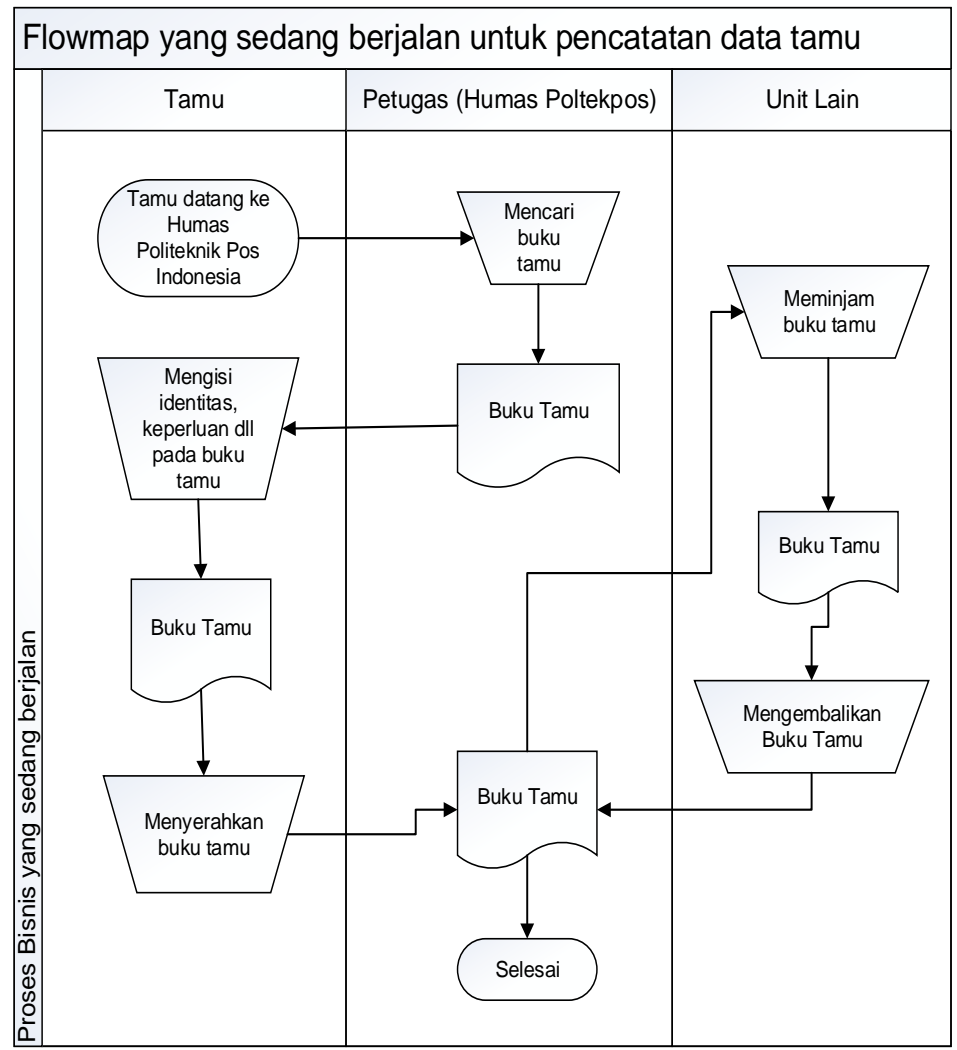

Gambar 3. Flowmap yang sedang berjalan

Keterangan system yang sedang berjalan dapat dilihat pada gambar diatas

1. Tamu datang ke humas \& rekrutmen Politeknik Pos Indonesia (Poltekpos)

2. Tamu Mengisi identitas, keperluan dll pada buku tamu yang sudah disediakan

3. Tamu menyerahkan buku tamu yang sudah diisi identitas, keperluan dll

4. Petugas (Humas Poltekpos) mencari buku tamu dan menyerahkan dan menerima kembali buku tamu

5. Unit lain meminjam buku tamu dan mengembalikan buku tapi jika sudah tidak diperlukan 


\subsection{Analisis sistem yang akan dibangun}

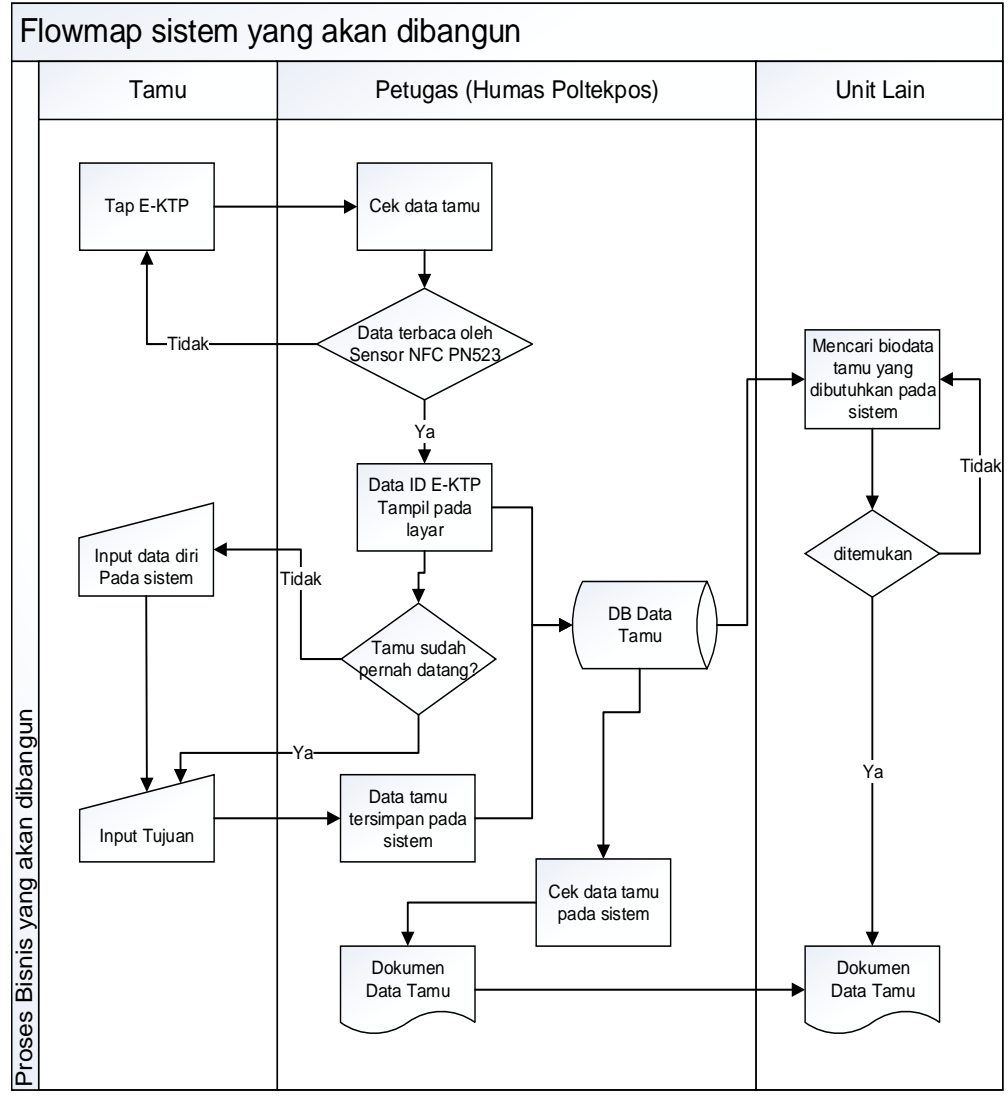

Gambar 4. Flowmap sistem yang akan dibangun

Keterangan system yang sedang berjalan dapat dilihat pada gambar 4 diatas

1. Tamu melakukan tapping E-KTP pada alat pencatat data tamu

2. Tamu mengisi data diri secara lengkap setelah ID E-KTP Terbaca

3. Tamu mengisi data tujuan

4. Tamu sudah pernah datang maka mengisi tujuan kedatangan

5. Petugas melakukan pengecekan data pada system

6. Petugas melihat hasil dari record ID E-KTP

7. Petugas mengecek data tamu

8. Petugas mencetak data tamu jika dibutuhkan

9. Unit lain mencari data tamu

10. Unit lain mendapatkan informasi kontak person pada buku tamu

\subsection{UML (Unified Modeling Language)}

Unified Modeling Language (UML) adalah suatu teknik pemodelan untuk pemrograman berorientasi objek serta penjabaran tentang aplikasi yang akan dirancang (A. Norma, 2014)). 


\subsubsection{Use Case Diagram}

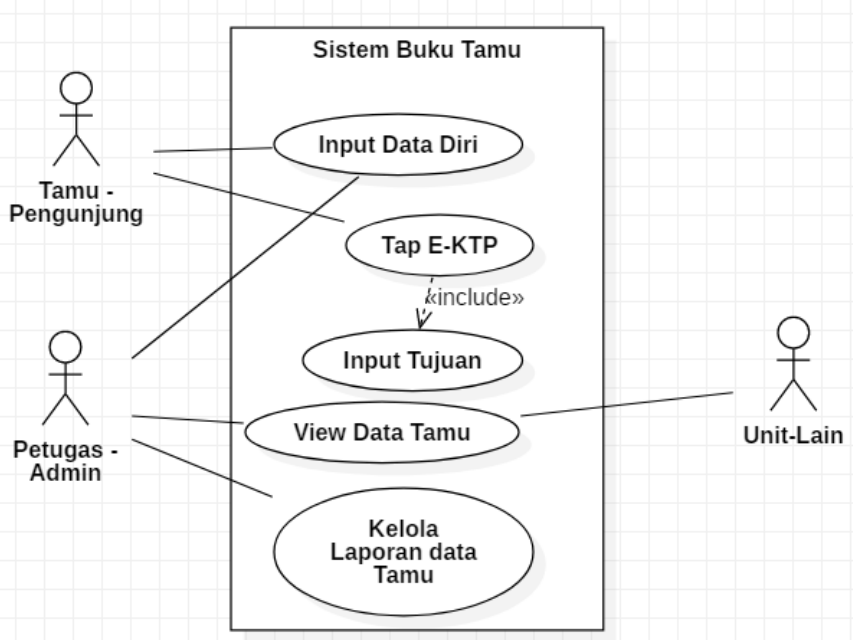

Gambar 5. Use Case Diagram Pencatatan Data Tamu dan Data Petugas

Keterangan aktor pada gambar 5 diatas didefinisikan dalam bentuk table dibawah ini

Tabel 1. Definisi Aktor

\begin{tabular}{|c|l|l|}
\hline No & \multicolumn{1}{|c|}{ Aktor } & \multicolumn{1}{c|}{ Keterangan } \\
\hline 1. & Tamu & Tapping E-KTP, Input data diri dan input tujuan \\
\hline 2. & Petugas & Input data E-KTP, Lihat data tamu dan kelola laporan data tamu \\
\hline 3. & Unit Lain & Melihat data tamu \\
\hline
\end{tabular}

Tabel 2. Definisi Use Case Tamu-Pengunjung

\begin{tabular}{|c|l|l|}
\hline No & \multicolumn{1}{|c|}{ Aksi } & \multicolumn{1}{c|}{ Keterangan } \\
\hline 1. & Tap E-KTP & Proses pembacaan NFC pada E-KTP \\
\hline 2. & Input Data Diri & Melakukan pengisian biodata setelah ID E-KTP terbaca \\
\hline 3. & Input Tujuan & Melakukan pengisian tujuan \\
\hline
\end{tabular}

Tabel 3. Definisi Use Case Petugas

\begin{tabular}{|c|l|l|}
\hline No & \multicolumn{1}{|c|}{ Aksi } & \multicolumn{1}{c|}{ Keterangan } \\
\hline 1. & Input Data Diri & $\begin{array}{l}\text { Membantu tamu melakukan pengisian biodata setelah ID E-KTP } \\
\text { terbaca }\end{array}$ \\
\hline 2. & View data tamu & Melakukan pengecekan data tamu pada sistem \\
\hline 3. & $\begin{array}{l}\text { Kelola laporan } \\
\text { data tamu }\end{array}$ & Melakukan kelola laporan data tamu \\
\hline
\end{tabular}

Tabel 4. Definisi Use Case Unit Lain

\begin{tabular}{|c|c|l|}
\hline No & Aksi & \multicolumn{1}{c|}{ Keterangan } \\
\hline 1. & View data tamu & $\begin{array}{l}\text { Melakukan pengecekan data tamu pada system jika ditemukan } \\
\text { maka data tersebut dapat digunakan untuk kebutuhan unit } \\
\text { tersebut }\end{array}$ \\
\hline
\end{tabular}




\subsection{Perancangan User Interface}

\subsubsection{User Interface halaman utama}

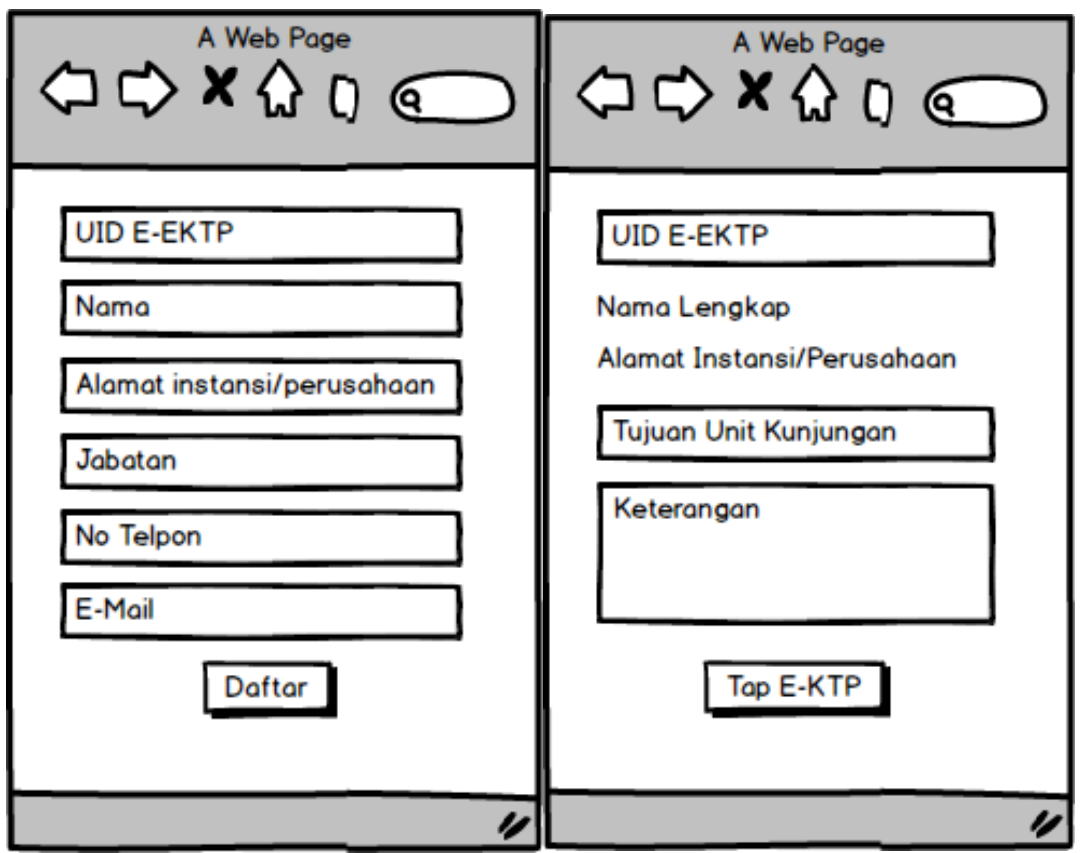

Gambar 6. User Interface Halaman Utama Sistem

Pada Menu halaman utama terdapat beberapa fitur berikut penjelasannya

1. UID E-KTP : Data yang diambil dari hasil tapping $e-k t p$

2. Nama berisi nama tamu yang akan diinputkan jika sudah hanya tinggal mengisi tujuan dan keterangan saja

3. Alamat instansi/perusahaan berisikan data instansi tamu yang datang

4. Jabatan berisi data jabatan tamu yang datang

5. No Telpon untuk memudahkan komunikasi apabila dibutuhkan

6. Email pengiriman berkas

7. Daftar akan digunakan untuk mendaftarkan tamu yang pertama kali datang

8. Tap-E-KTP jika data sudah terisi lakukan ujicoba kembali dengan cara tap e-ktp untuk memastikan data terekap oleh sistem (optional)

\subsubsection{User Interface kelola buku tamu}

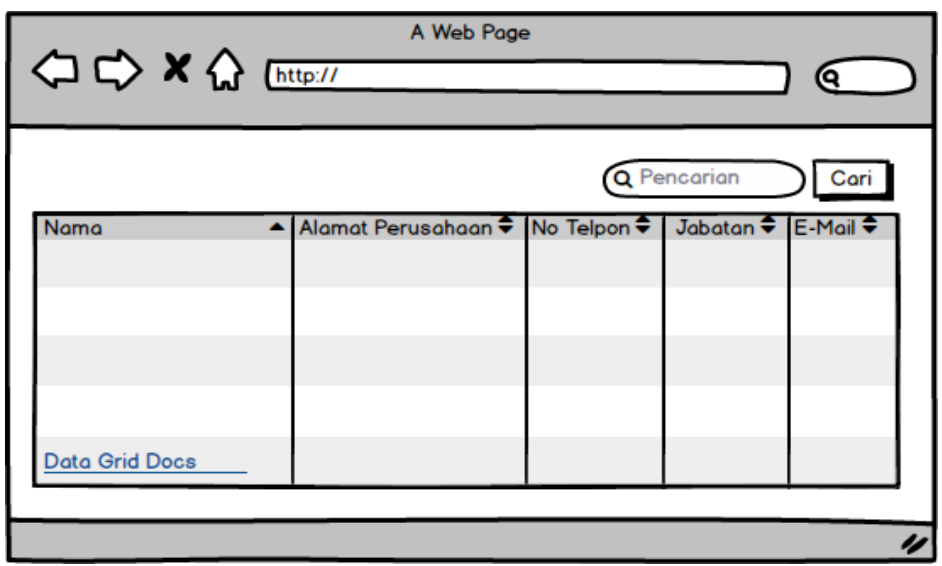

Gambar 7. User Interface Halaman Kelola Buku Tamu

http://ejurnal.poltekpos.ac.id/index.php/competitive | 82 
Pada Menu halaman kelola buku tamu terdapat beberapa fitur berikut penjelasannya

1. Pencarian untuk mengetikan nama tamu yang akan ditampilkan

2. Button Cari berfungsi untuk menjalankan aksi pada system sehingga data tamu bias tampil sesuai dengan yang dibutuhkan

3. Tabel data tamu akan menampilkan data tamu yang datang

\subsubsection{User Interface Hardwae}

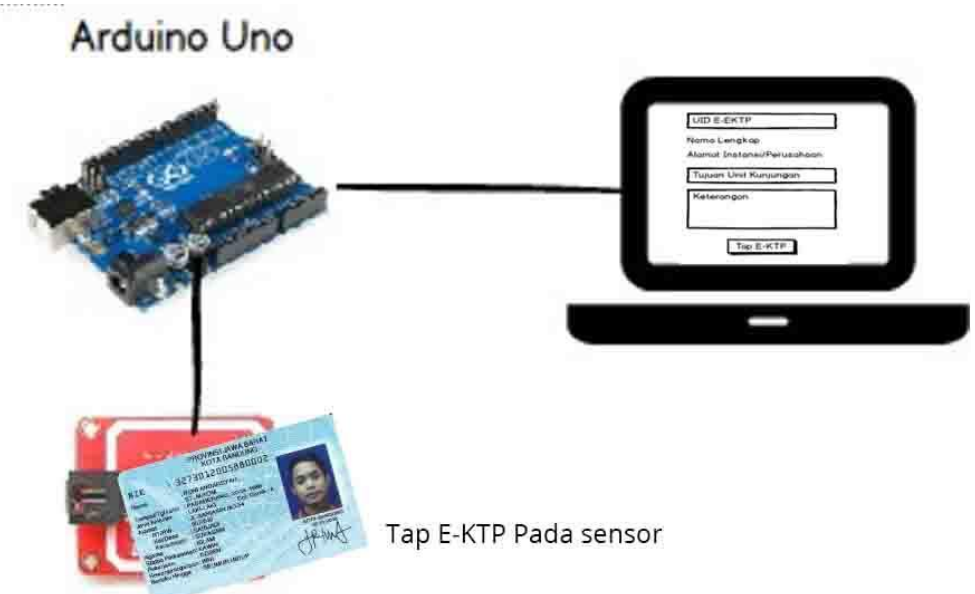

\section{Sensor NFC PN532}

Gambar 9. User Interface Hardware

Pada perancangan Hardware terdiri dari sebagai berikut :

1. Sensor NFC PN532 berfungsi untuk membaca E-KTP

2. Arduino Uno akan melakukan conversi data sehingga dapat ditampilkan pada layar

3. Layar Komputer akan menampilkan data ID E-KTP yang sudah didaftarkan atau di validasi

\subsubsection{Tampilan Hasil Uji Tapping E-KTP}

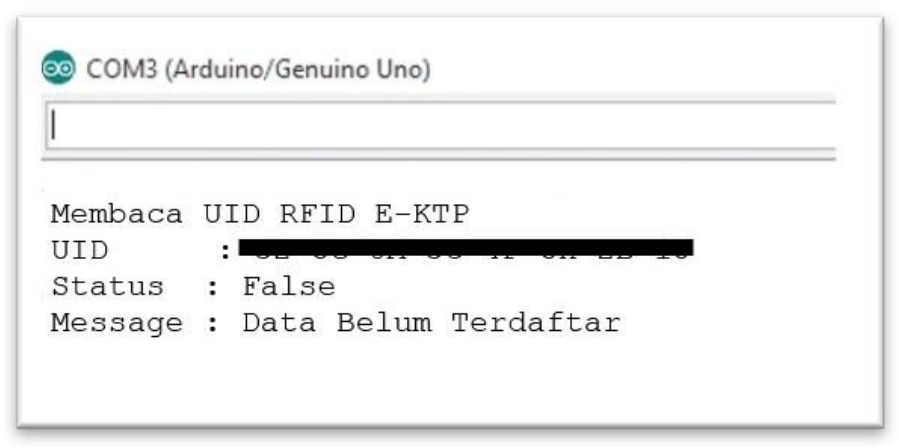

Gambar 10. Hasil uji jika data E-KTP belum pernah didaftarkan 


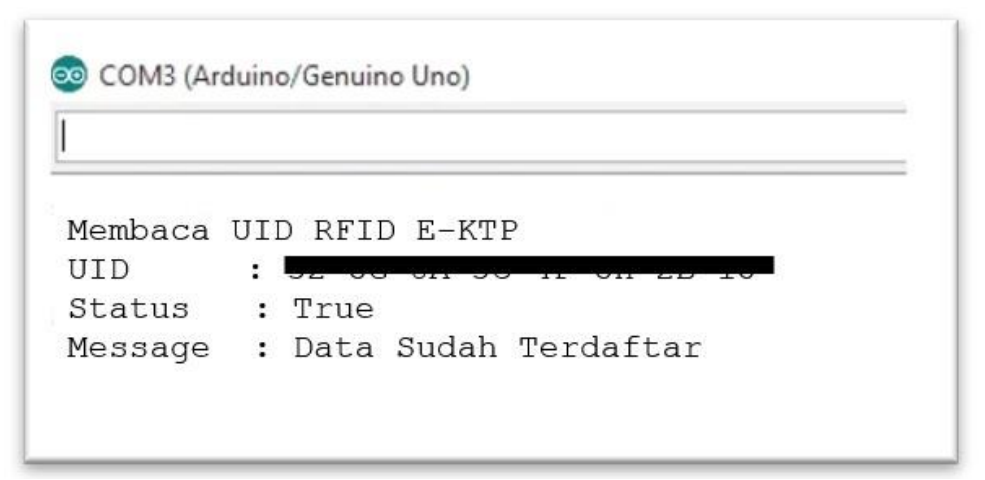

Gambar 10. Hasil uji jika data E-KTP sudah terdaftar

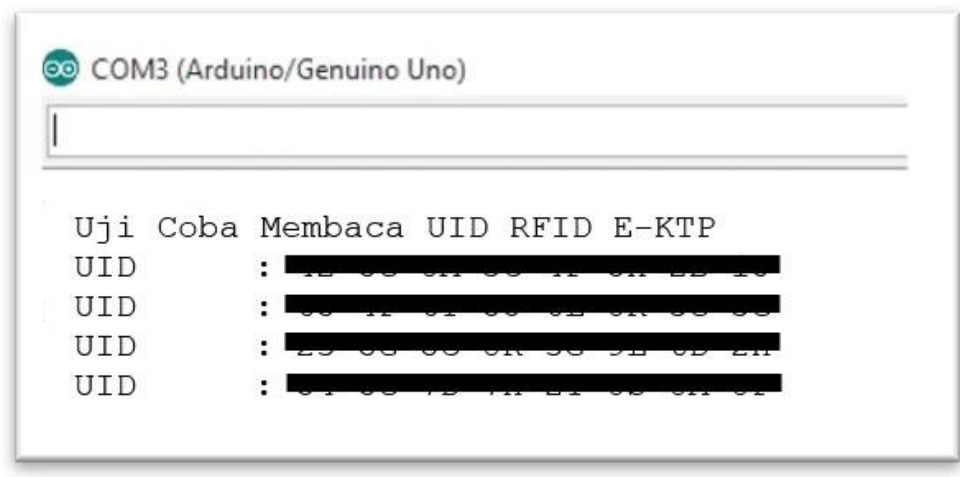

Gambar 11. Tampilan data E-KTP yang sudah terdaftar pada system Arduino sebelum dipanggil dan ditampilkan pada aplikasi

\section{KESIMPULAN}

\subsection{Kesimpulan Hasil Perancangan}

Berdasarkan hasil perancangan dan pengujian yang telah dilakukan, maka dapat disimpulkan sebagai berikut

1. Data pengunjung tidak terjadi duplikasi karena data berdasarkan id pada E-KTP

2. Data pengunjung dapat diakses oleh seluruh unit yang ada dilingkungan Politeknik Pos Indonesia

3. Pengelolaan laporan buku tamu dapat dilakukan dengan mudah.

4. Pencatatan buku tamu menjadi lebih cepat karena tamu cukup melakukan tapping E-KTP dan mengisi tujuan saja.

5. Pencarian data Tamu oleh seluruh unit menjadi lebih mudah karena adanya fasilitas pencarian data.

\subsection{Saran}

Dari kesimpulan diatas maka ada beberapa saran untuk pengembangan kedepan yaitu

1. Untuk penelitian selanjutnya diharapkan dapat dikembangkan aplikasi berbasis mobile yang dapat memberikan flesibilitas lebih tinggi

2. Data pada E-KTP dapat dibaca secara utuh tidak hanya id kartu pada E-KTP saja.

\section{REFERENSI}

B. D. Fajar Agung, "Perancangan dan Prototype Aplikasi Presensi Perkuliahan dengan Menggunakan android pada wireless sensor network," 2014.

S. H. P. A. Galih Idhar Permana, "Implementasi Smart Payment Sistem Untuk Pengunjung Kolam Renang Telkom University Menggunkana Nfc," 2013.

A. Pratama, "Eksploitasi Rfid Menggunakan Nfc Dengan Teknik Cloning Pada Studi Kasus Kt," 2015. http://ejurnal.poltekpos.ac.id/index.php/competitive | 84 
S. M. N. A. N. J. Soraya Qonnita Aisyah, "Perancangan Dan Implementasi Sistem Akses Kontrol Pada Pintu Berbasis Teknologi Near Field Communication Dengan Mikrokontroler Arduino Uno," 2014.

H. I. H. Farid Mubarok, "Perbandingan Antara Metode RUP dan Prototype Dalam Aplikasi Penerimaan Siswa Baru Berbasis Web," 2015.

F. Electonics, "How to Use NFC Shield with Arduino and Demo Code," 2013.

N. f. b. philips, "UM0701-02 PN532 User Manual," 2007.

S. T. R. . U. A. Norma Dewi Suryani, "Optimalisasi Teknologi Biometrics Dalam Program e-KTP Dengan Penambahan Data Struktur Gigi Dan Kartu Sakti Sebagai Alternatif Satu Kartu Multifungsi," 2014.

M. A. . S. P. Ema Fadlilatul Nurul Jihan, "Prototipe Absensi Cerdas menggunakan Wi-Fi Studi Kasus : Pegawai Fakultas Informatika," 2015. 